\title{
The Instructional Design Flipped Mastery Classroom Model Using Virtual Classroom System with Problem-Based toward Problem Solving Ability
}

\author{
Rukthin Laoha ${ }^{1 *}$, Pallop Piriyasurawong ${ }^{2}$ \\ ${ }^{1}$ Division of Management Information System Faculty of Science and Technology Rajabhat Maha sarakham \\ University, Thailand. \\ 2 Division of Information and Communication Technology for Education Faculty of Technical Education King \\ Mongkut's University of Technology North Bangkok, Bangkok, Thailand.
}

* Corresponding author. Tel.: +669 4142 7770; email: Rukthin094@gmail.com

Manuscript submitted February 25, 2017; accepted May 16, 2017.

doi: 10.17706/ijeeee.2018.8.1.18-25

\begin{abstract}
The purposes of this research were (1) to develop The Instructional Design Flipped Mastery Classroom Model Using Virtual Classroom System with Problem-Based toward Problem Solving Ability and (2) to validate the efficiency of the learning model developed. The research consisted of 4 stages. There were analysis and literature review, front-end analysis, learning model design and the model tool evaluation creation. The samples were 5 experts in the field of flipped Classroom, information technology, and education technology selected by purposive sampling. Data collection tools were the system and the assessment of appropriate model with 5-level rating scale. The statistics used in data analysis were means and standard deviation. The results showed that (1) The Instructional Design Flipped Mastery Classroom Model Using Virtual Classroom System with Problem-Based toward Problem Solving Ability process by system approach consists of 10 inputs factors, 10 process factors, 2 output factors and 1 feedback. And (2) Evaluation of five experts the instruction model has commented instruction model developed in an overview that was the most appropriate $(\overline{\mathrm{x}}=4.70$, S.D. $=0.42)$.
\end{abstract}

Key words: Flipped classroom, mastery learning, problem based learning, problem solving ability.

\section{Introduction}

Learning in 21st century, teacher's role changes from lecturer to the team of learning activity designers in learning process so that learners can construct their own knowledge. Teacher is a facilitator, suggesting tools for accessing knowledge widely and fast, especially technology. Then learners exchange their knowledge in class. This process is called "Active Learning". Panitch [1] reveals that subject content is important but not sufficient for learning for survival in 21st century. He adds that nowadays content or subject matter learning should be done by learners discovering knowledge by themselves and teacher providing advises, designing activities that help each learner assesses learning progress and create interning varied skill in learning process.

Concept changes [2] for creating educational innovation under 21st framework which focuses on the new generation preparation for the changing and boundless world, all sectors give priority to information technology progress and the world citizen cooperation. Therefore, flipped classroom becomes method innovation that encourages learners apply knowledge in situations for mastery learning. 
The researchers realize the importance of learning process that conforms to the 21st century learning so they develop Flipped Mastery Classroom Model Using Virtual Classroom System with Problem Based toward Problem Solving Ability. They design mastery learning model with flipped classroom process based on problem solving activities. Mastery learning was introduced by Washburn in 1992, [1]. At first it was not very popular because it increased teacher's work. But today ICT makes it possible without teacher's overloading. The researchers develop virtual classroom system that supports learning model designed. The main principle of mastery learning is each learner achieved goals depending on one's leaning ability speed. Flipped Mastery Learning [3] is the model that the learners master their learning using modern technology to create learning atmosphere. It is the class that each learner or each class or group has one own different lesson. Each learner or each class is interested in doing one own activity. Each learner does activity for his or her own learning. The researchers design virtual classroom as a tool supporting flipped mastery learning achievement. It is a resource that learner can learn independently anywhere anytime. It is the area for learners to learn together, exchange one another's knowledge, assess and evaluate one own's progress. And finally, the system receives learners' feedback and submits it to teacher for learning improvement.

\section{Objective}

1) To design Flipped Mastery Classroom Model Using Virtual Classroom System with Problem Based toward Problem Solving Ability.

2) To evaluate learning model developed by experts.

\section{Literature Review}

In the development of, Flipped Mastery Classroom Model Using Virtual Classroom System with Problem-Based toward Problem Solving Ability there are related research and literature which were studied and can be concluded as follows:

\subsection{Flipped Classroom and Mastery Learning}

The flipped classroom is an instructional model in which learning content is not presented during the in-class time [4], [5], but rather is learned by students prior to the classroom meetings, then in-class time is used for student centered, active learning [6]. In contrast to a traditional, lecture-based, instructor-centered instructional model, the flipped classroom model is composed of two phases of instruction that are "flipped," "inverted," or "reversed". [3]

Bergmann and Sams [3] Mastery learning has been around for quite some time. It was first introduced in the 1920s, but it got little attention until the 1960s, when it was popularized by Benjamin Bloom. He likened our present educational institutions to a race where only the fastest learners were rewarded. He argued that almost all students can master any content, given enough time and support. When mastery learning was implemented well, studies showed that nearly $80 \%$ of all students could learn all of the important content compared to $20 \%$ taught with the traditional model.

The basic idea of mastery learning is for students to learn a series of objectives at their own pace. Instead of all students working on the same topics at the same time, all of them work toward predetermined objectives.

Mastery learning is usually done in a course with a discrete body of knowledge in which mastery of one objective is necessary for success in all subsequent objectives.

Components of a Flipped-Mastery Classroom

1) Establish clear learning objectives.

2) Determine which of these objectives are best achieved through inquiry, and which are best learned through direct instruction. 
3) Assure student access to videos.

4) Incorporate engaging learning activities to be done in class.

5) Create multiple versions of each summative assessment for student.

\subsection{Advantages and Disadvantages of Flipped Classroom}

\subsubsection{Advantages of flipped classrooms}

With any initiative [7] there are benefits and drawbacks. If the model of the flipped classroom is used correctly, the benefits are immense. One of the biggest draws to implementing the flipped classroom is the positive feedback from students. In the $21^{\text {st }}$ century, students are accustomed to high-tech gadgets and social media. They use these gadgets and resources as entertainment: why not use them as a means for instruction as well? Students are also immersed in the Internet and social media, and for many, have grown up only knowing these entities as an integral part of life, though they may not be savvy in best use practices.

\subsubsection{Disadvantages of flipped classroom}

Educators found some problems with using the flipped classroom. The flipped model cannot inclusively use video for home viewing [8]. Using traditional lecture online rather than in the classroom did nothing to shift the type of learning for students. Brunsell and Horejsi [9] emphasized an increase in active and engaging learning experiences along with the online videos was a more complete classroom flip than just showing online videos. A student that showed apathy in the classroom before flipping would continue to be apathetic after the flip even when given them more freedom in the educational model [10]. If students did not have access to internet for viewing videos online, then teachers had to identify new ways of connecting those students to the presented information. Spingen identified this as the digital divide. Students that could not afford a computer at home or did not have internet access, or a device given to them to watch videos would be left behind. Schools that wanted flipped classrooms needed to address this issue by allowing better access at school. Depending on the budget of the school district, the cost of flipping a classroom can be significant or reasonable with proper choices of technology [11]. Good teachers using poor technology could still have been successful in the classroom; although, the use of technology could not make a poor teacher better [12].

\subsection{Flipped-mastery classroom}

A flipped-mastery classroom [3] takes the principles of mastery learning and marries them with modern technology to make a sustainable, reproducible, and manageable environment for learning. If you were to walk into one of our classrooms, you would see much asynchronous activity. Basically, all students are working on different activities at different times. Our students are busy and engaged in their learning. Teachers would see some students conducting experiments or other inquiry activities, some watching videos on their personal devices, some working in groups mastering objectives, some interacting with the whiteboard to engage with online simulations, some studying in small groups, and some taking assessments on either a school computer or their own personal device.

\subsection{Flipped Classroom Resources}

Aside from management concerns by teachers, many wonder where they even begin to get started in realistically reforming their curriculum and instruction. The logistics of the flipped classroom are well worth a look. A great place to start is somewhere together. Fulton reports that Byron High School used their Professional Learning Community time (PLC) to collaborate and begin making their videos. Teachers have many more options in creating videos than just recording themselves. Teachers can find and share videos on www.youtube.com [13] as well as look online at places like Khan Academy to find pre-existing videos Teachers can also scour the Internet for existing Web Quests that will make the learning more project based 
as well. Other teachers have taken existing Power Points and turned them into videos by making them Screencasts [3]. However, some teachers simply video tape themselves using a video camera or use software applications like Educreations to help students visualize the process they are being taught. Once the videos and lessons are recorded, school districts can utilize programs such as Moodle, Schoology, or Blackboard to upload and share the videos. Schools can also simply burn the lessons to DVDs or flash drives, but the strain on time becomes more apparent. 16 All the literature shares the same message: the shift cannot happen in one year. Teachers can begin with one unit and begin flipping their instruction. Maybe it is only one lesson to start with. Either way, the shift will not happen overnight, and teachers need to realize that once the lesson is recorded, it can be used again and again, just like they would give that same lecture year after year.

\section{Materials and Methods}

The research on the development of Flipped Mastery Classroom Model Using Virtual Classroom System with Problem-Based toward Problem Solving Ability, it was studied according to the following parts.

1) Target group and Variable.

2) Research tools.

3) Data Analysis.

4) Design Procedure.

\subsection{Target Group and Variable}

Target:

Target group are instructional design and information technology experts, 2 instructional design experts and 3 information technology experts. Purposing sampling technique is used for acquiring the target group. Variable: Independent variables are Flipped Mastery Classroom, Problem Based Learning and Virtual Classroom. Dependent variable is Flipped Mastery Classroom Model Using Virtual Classroom System with Problem Based toward Problem Solving Ability.

\subsection{Research Tools}

The research instruments were an evaluation Flipped Mastery Classroom Model Using Virtual Classroom System with Problem-Based toward Problem Solving Ability.

\subsection{Data Analysis}

The data obtained from the experts were collected and analyzed by using the statistics as follows:

1) Arithmetic mean

2) Standard deviation.

\subsection{Design Procedure}

The researchers designed 4 stages Flipped Mastery Classroom Model Using Virtual Classroom System with Problem Based toward Problem Solving Ability [14]-[16].

Stages1: Analysis and literature review.

1) Study Flipped Classroom literatures

2) Study Mastery Learning Theory literatures.

3) Study Problem Solving Ability literatures.

4) Study Problem Based learning literature.

5) Study Virtual Classroom literatures.

Stages2: Front-end analysis. 
1) Analyze context including needs, curriculum and lesson.

2) Analyze leaners.

3) Analyze learning tasks.

Stages3: Designed Flipped Mastery Classroom Model Using Virtual Classroom System with Problem Based toward Problem Solving Ability following System Approach. The System Approach instruction model synthesizing consisted of Input - Process- Output. Then the instructional model developed was examined by experts and revised based on the expert comments and suggestions.

Stages4: Created evaluation instrument to evaluate the learning model. Then The evaluation instrument was examined the Index of Item Objective Congruence value (IOC) by experts. And finally, the learning model was presented to the experts to examine and conclude the evaluation result.

\section{Conceptual Framework}

The framework of the study consists of independent variable and dependent, following Fig. 1.

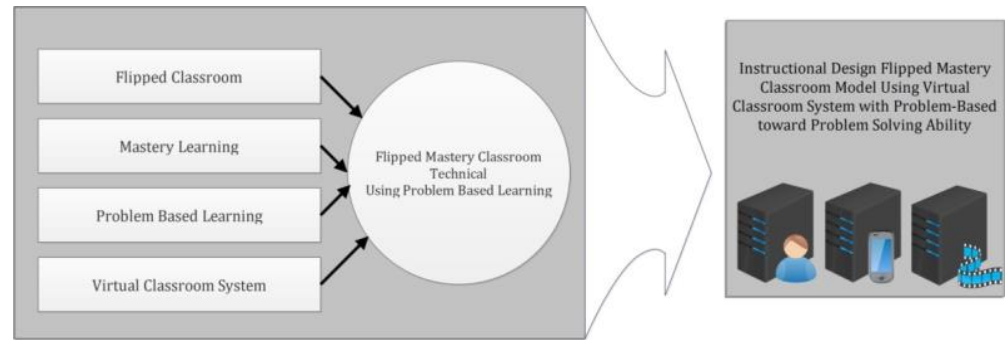

Fig. 1. Frame of model.

\section{Result}

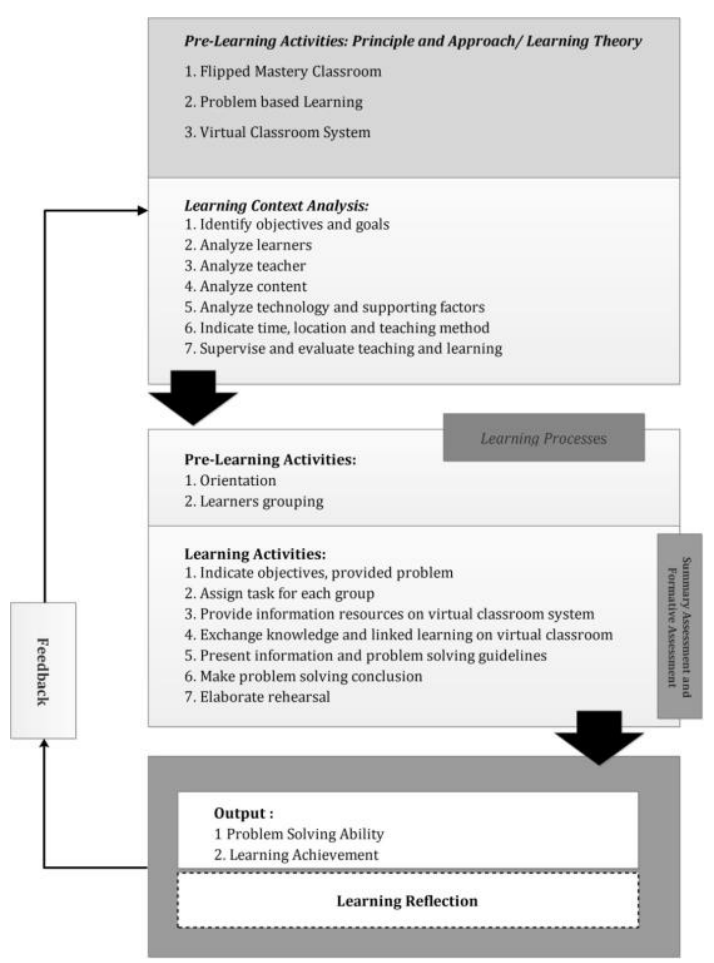

Fig. 2. Flipped mastery classroom model using virtual classroom system problem-based toward problem solving ability. 
Flipped Mastery Classroom Model Using Virtual Classroom System with Problem-Based toward Problem Solving Ability included 4 component.

Component 1 Input consisted of 2 main factors and 10 activities.

The main factor 1: Pre-Learning Activities consisted of Principle and Approach/ Learning Theory.

1) Flipped Mastery Classroom.

2) Problem Based Learning.

3) Virtual Classroom System.

The main factor 2: Learning context analyzing consisted of 7 factors.

1) Identify objectives and goals.

2) Analyze learners.

3) Analyze teacher .

4) Analyze content .

5) Analyze technology and supporting factors.

6) . Indicate time, location and teaching method.

7) Supervise and evaluated teaching and learning.

Component 2 was the teaching and learning activities that consisted of 2 Part and 10 processes. The component led to problem solving ability. The researchers synthesized Flipped Mastery Classroom learning and problem based for effectiveness. The researchers developed virtual room system to support learning process such as learning resources including VDO clip, file sharing and providing information sources. Virtual classroom was the area where learners chatted, exchanged and linked knowledge, submitted tasks, and the most important aspect of mastery learning, evaluated their knowledge and understanding which was called summative assessment for each objective. It consisted of 2 Part :

Part 1: pre- learning activities. There were 2 processes in this part.

Process 1: Pre-Learning.

1) Orientation

Orientation was the stage that the learners were presented content, teaching process, learning strategies, and criteria for grading and performance rules. The aim of this state was to guide and make understanding between teacher and learners.

2) Learner grouping.

Learners were grouped based on teacher.

Part 2: learning activity was divided into 7 processes

1) Indicate objectives, provide problem to learners.

2) Assign task for each group.

3) Provide information resources on virtual classroom system.

4) Exchange knowledge and link learning on virtual classroom. For example, teacher makes appointment with the groups for discussion, knowledge information sharing by chatting in virtual classroom. Teacher takes a role as an observer.

5) Present information and problem solving guidelines in classroom. When learners finish discussion and get proper answer, teacher assigns that learners find out their best presentations in classroom.

6) Make problem solving conclusion. Teacher and learner make conclusion of problem solution together.

7) Elaborate rehearsal. Teacher together with learners expand their thinking. When short term memory occurs, Teacher and learners expand their information by grouping and giving meaning. This leads to long term memory and develops sustainable problem solving ability.

The most important part that cannot missed is teacher assesses learners, both understand assessment 
(summative assessment) and assessment for improvement (formative assessment) every learning unit.

Component 3: output or outcome. There were 3 outcomes in this component.

1) Problem solving ability.

2) Learning Achievement.

3) Learning Reflection.

Component 4: feedback. There was 1 factor. It was used for model improvement.

Evaluate learning model developed by experts.

Evaluation of five experts the instruction model has commented instruction model developed in an overview that was the most appropriate $(\overline{\mathrm{x}}=4.70$, S.D. $=0.42)$.

Table 1. Evaluation the Model by Five Experts

\begin{tabular}{|c|c|c|c|}
\hline & $\overline{\mathbf{x}}$ & S.D. & Level \\
\hline $\begin{array}{l}\text { Component } 1 \text { Input consists of } 2 \text { main } \\
\text { factors and } 10 \text { activities. }\end{array}$ & 4.68 & 0.29 & most appropriate \\
\hline $\begin{array}{l}\text { Component } 2 \text { The teaching and learning } \\
\text { activities that consist of } 2 \text { factors and } 10 \\
\text { processes. }\end{array}$ & 4.56 & 0.51 & most appropriate \\
\hline $\begin{array}{l}\text { Component } 3 \text { output or outcome. There are } \\
3 \text { outcomes. }\end{array}$ & 4.76 & 0.43 & most appropriate \\
\hline $\begin{array}{l}\text { Component } 4 \text { Feedback. There is } 1 \text { factor. It } \\
\text { is used for model improvement. }\end{array}$ & 4.80 & 0.44 & most appropriate \\
\hline
\end{tabular}

\section{Conclusion}

The Instructional Design Flipped Mastery Classroom Model Using Virtual Classroom System with Problem-Based toward Problem Solving Ability consisted of 4 components. Component1, input consisted of 2 main factors and 10 activities. Component2, teaching and learning activities was consisted of 2 parts and 10 processes. Part1 was pre-learning activities and part 2 was learning activities. Component 3 was output and outcome. And the finally component 4 was feedback. There was 1 factor in feedback component. It was used for model improvement. The learning activities were support by virtual classroom system. The virtual classroom system worked as information or knowledge source. It was the area where students shared and exchanged their homework, worksheet or assignments. Therefore, it conformed to Bergmann, J and Sam, A' Flipped Classroom principle [3]. Evaluation of five experts in the field of flipped Classroom, information technology, and education technology the instruction model has commented instruction model developed in an overview that was the most appropriate.

\section{References}

[1] Panitch, V. (2013). Teacher for Student Make Flipped Classroom. Bangkok: SR Printing Mass Product Publishing.

[2] Pahe, S. (2013). The Flipped Classroom: New Classrooms Dimension in the 21st Century. Retrieved from the website: http://phd.mbuisc.ac.th/academic/flipped classroom2.pdf

[3] Bergmann, J, \& Sams, A. (2012). Flip your classroom: Reach every student in every class every day. Eugene, OR: International Society for Technology in Education.

[4] Baker, J. W. (2000). The "classroom flip": Using web course management tools to become the guide by the side. Proceedings of the 11th International Conference on College Teaching and Learning. Jacksonville, FL.

[5] Strayer, J. F. (2012). How learning in an inverted classroom influences cooperation, innovation and task orientation. Learning Environments Research, 15(2), 171-193. 
[6] Bland, L. (2006). Applying flip/inverted classroom model in electrical engineering to establish life-long learning. The American Society of Engineering Education Conference and Exposition. Chicago, IL.

[7] Gross, A. L. (2014). The flipped classroom: Shakespeare in the english classroom(Order No. 1569865). ProQuest Dissertations \& Theses Global. Retrieved from the website: http://search.proquest.com/docview/1641121557?accountid=43140

[8] Milman, N. B. (2012). The flipped classroom strategy: What is it and how can it best be used? Distance Education, 9(3), 85-87.

[9] Brunsell, E., \& Horejsi, M. (2013). A flipped classroom in action. The Science Teacher, 80(2).

[10] Springen, K. (April 2013). Flipped: A revolutionary approach to learning presents pros and cons for educators. School Library Journal, 59(4), 23-26.

[11] Lage, M. L., Platt,and, G. J., \& Treglia, M. (2000). Inverting the Classroom: A gateway to creating an inclusive learning environment. Journal of Economic Education, 31(1), 30-43.

[12] Levy, R., Dickerson, C., \& Teague, J. (2012). Developing learning resources and strategies to support academic reading: a student-centered approach. Journal of Further and Higher Education, 35(1).

[13] Defour, M. (2016). Flipped classrooms. Spreading in Wisconsin. Community College Week, 25(16), 10.

[14] Jeerungsuwan, N. (2015). Instructional Design and Assessment. Bangkok: King Mongkut's University of Technology North Bangkok Publishing.

[15] Prangsorn, S., Piriyasurawong, P., \& Nilssok, P. (2014). Instructional model with webquest using problem-based toward problem solving ability and critical thinking. Education. Technical Education Journal King Mongkut's University of Technology North Bangkok, 24-33.

[16] Pongsawat, P., \& Jeerungsuwan, N. (2015). The instruction design flipped classroom model by using WebQuest activities to develop learning skills in the 21st century for students in higher education. Technical Education Journal King Mongkut's University of Technology North Bangkok, 151-158.

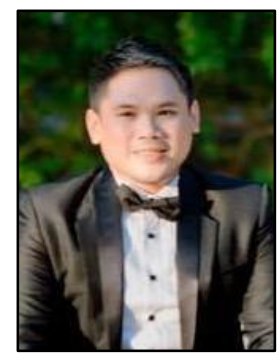

Rukthin Laoha was born in KhonKaen, Thailand. He graduated management information system from Mahasarakham University Thailand and the master's degree from Khonkaen University, Thailand. And now he is Ph.D. student in division of information and communication technology for Education Faculty of Technical Education King Mongkut's University of Technology North Bangkok.

At present, Mr. Rukthin Laoha is lecturer of Division of Management Information System Faculty of Science and Technology Rajabhat Maha sarakham University, Thailand. His research interest includes management information systems, data mining, data science and education technology.

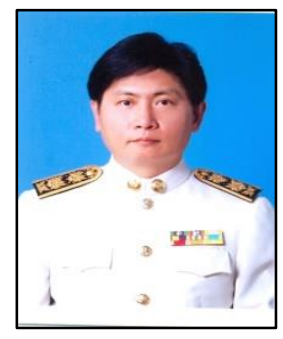

Pallop Piriyasurawong is assistant professor of division of information and communication technology for Education Faculty of Technical Education King Mongkut's University of Technology North Bangkok. His area of current interest includes ICT for education, innovation for education etc. 